\title{
COMMUNITY EMPOWERMENT THROUGH WASTE MANAGEMENT INTO ECONOMIC VALUE IN BABAKAN NGANTAI VILLAGE KARANG TENGAH SENTUL BOGOR
}

\author{
Dewi ANGGRAINI and Islamiah KAMIL \\ Dian Nusantara University \\ dewi.anggarini@undira.ac.id; islamiah.kamil@undira.ac.id
}

\begin{abstract}
Garbage is the biggest problem for the residents of Babakan Ngantai, Karang Tengah Sentul Village, Bogor, because people still think with the old pattern that rivers are garbage dumps, and waste must be burned completely, resulting in no waste management and polluting the environment. One of the things that must be done to overcome this problem is to manage the waste so that it becomes an item of aesthetic value, namely by making handicrafts in the form of glass mineral water containers and tissue containers using waste plastic cups, used mineral water and used cardboard. Conduct training for mothers gentlemen and young people about how to make handicrafts in the form of glass mineral water containers and tissue containers using plastic mineral water glass and cardboard waste that can have economic selling value, which is one of the programs we carry out. The Management of Used Plastic and Cardboard Waste is expected to be able to empower the community and provide awareness for the community to be more concerned with waste. Community Empowerment is an effort made to increase public awareness about waste and Instilling modern cultural values such as hard work, frugality, openness, responsibility is an important part of empowerment efforts. The Management of Used Plastic and Cardboard Waste is expected to be able to empower the community and provide awareness for the community to be more concerned with waste. Community Empowerment is an effort made to increase public awareness about waste and Instilling modern cultural values such as hard work, frugality, openness, responsibility is an important part of empowerment efforts. The Management of Used Plastic and Cardboard Waste is expected to be able to empower the community and provide awareness for the community to be more concerned with waste. Community Empowerment is an effort made to increase public awareness about waste and Instilling modern cultural values such as hard work, frugality, openness, responsibility is an important part of empowerment efforts.
\end{abstract}

Keywords: Plastic Waste Management, Used Cardboard, Community Empowerment, Simulation

\section{BACKGROUND}

Increasing environmental pollution is caused by various things, such as the increase in the human population which results in an increase in the amount of waste being disposed of. This is exacerbated by inadequate places and locations for waste disposal, lack of awareness and willingness of the community in managing and disposing of waste, the lack of public understanding of the benefits of waste, as well as the reluctance of the community to reuse waste, because waste is considered as something dirty, various things that cause environmental degradation which has a negative impact on society. Garbage is the biggest problem for the residents of Babakan Ngantai, Karang Tengah Sentul Village, Bogor, because people who still think with the old pattern that rivers are landfills, and garbage must be burned completely.

In this case, the current problem in Babakan Ngantai, Karang Tengah Sentul Village, Bogor, is related to the waste management system. There is still household waste scattered around the Babakan Ngantai, Karang Tengah Village, Sentul Bogor. Garbage originating from households is the biggest contribution to waste generation, besides that household waste is hazardous waste because it is categorized as B3 waste (Hazardous Toxic Materials).

According to Sumodiningrat (1999) in Apri Susanto, et al (2020), that community empowerment is an effort to make the community independent through the realization of the potential abilities they have. The community has an important role in these activities, besides being a producer of waste every day, the community is also directly involved in these activities. Through the community empowerment approach, it is expected to increase public awareness and improve community skills and independence so that these activities can run well and sustainably. Community involvement can be started from changing behavior in the use of items that have the potential to become waste, utilizing waste that is still fit for use (reuse) and recycling waste into new products (recycle).

But in the implementation of community empowerment activities in waste management in reducing plastic waste, it still causes several problems in waste management including the presence of garbage in TPS and trash cans that should be reused by the community such as drink bottles, cans etc. There is still a mixture of organic and inorganic waste in the segregation and waste transportation tanks. The mixing of the waste will hamper the waste processing process because people have to sort the waste first before processing the waste so that it takes longer to process the waste. If this is left unchecked, it will become a breeding ground for mosquitoes which can later cause disease in the community.

Judging from some of the problems above, the main problem that arises is that people are still not involved and able to empower waste management activities in reducing plastic waste and used cardboard. For this reason, the question for this Community Service is "How is Community Empowerment through Waste Management in Reducing Waste of Plastic Mineral Water Glass Packaging and Used Cardboards in Babakan Ngantai The purpose of this community service is to study community empowerment through waste management in reducing waste of plastic mineral water glass packaging and used 
cardboard in Babakan Ngantai, Karang Tengah Sentul Village, Bogor.

The benefits of this community service for the future are to provide an overview of community empowerment in waste management, provide input for the government as an alternative in dealing with solid waste problems in Babakan Ngantai, Karang Tengah Sentul Village, Bogor and provide an overview of community waste management that can also reduce plastic waste because it reduces waste directly from the source.

Waste management aims to improve public health and environmental quality and make waste as a resource. From the point of view of environmental health, waste management is considered good if the waste does not become a medium for breeding disease germs and the waste does not become an intermediary medium for the spread of a disease. Other conditions that must be met, namely not polluting air, water and soil, do not cause odors (do not interfere with aesthetic values), do not cause fires and others.

Based on the real conditions described in the Situation Analysis sub-chapter above, the problems can be grouped as follows.

1. Lack of insight and motivation to desire to create a healthier and better life.

2. The low level of behavior change and the level of creative business ability and the low skill/creativity of processing plastic waste

\section{METHOD}

The implementation method is:

1. Socialization that is able to increase business insight in terms of knowledge about Empowerment of Used Plastic and Cardboard Waste as products of economic value

2. Observations were carried out to find out the partner's condition further, such as conditions in Babakan Ngantai, Karang Tengah Village, Sentul Bogor, availability of time and place, environmental conditions. Observations were also carried out in order to prepare the place, materials and tools for the implementation of this PPM. Site preparation is carried out to find a place where it will be used as a place for socialization to increase knowledge about Empowerment of Used Plastic and Cardboard Waste as products of economic value and plastic waste for health and the environment as well as opportunities that can be developed from the potential of plastic waste and used cardboard into recycled products economic value, creative and useful

3. Simulation workshop of opportunities that can be developed from the potential of used plastic and cardboard waste into creative, economical and useful recycled products

Evaluation of program achievement is a summary of the results of measuring the achievement of output targets after the completion of this program. The achievement of the output targets is measured using various performance indicators that have been set and is a measure of the success of the program. Evaluation of the achievement of output targets is carried out, among others, by changing the behavior of successful communities before and after socialization, opportunities for creativity and innovation before and after education, the ability to socialize and implement knowledge about Empowerment of Plastic Waste and Used Cardboard as products of economic value. Utilizing this plastic waste into creative products and services in order to manage plastic waste properly, so that plastic really supports our lives. As a creative product, the creation of plastic waste has a promising commercial value. This product has a selling power that can generate profits. In general, this business is divided into two types, namely products and services.

The sustainability of this activity can be maintained through online service facilities that will be established between UNDIRA and partner groups. In addition, UNDIRA provides service funds and there are also opportunities to obtain external service funds that can be used to continue fostering partner groups

\section{RESULTS AND DISCUSSION}

This Community Service Program is carried out in the following forms:

1. Presentation of Training Materials Waste Management in Reducing Waste of Plastic Mineral Water Glass Packaging and Used Cardboard

2. Briefing for Inner community Waste Management in Reducing Waste of Plastic Mineral Water Glass Packaging and Used Cardboard

3. Implementation on Inner community Waste Management in Reducing Waste of Plastic Mineral Water Glass Packaging and Used Cardboard.

4. Motivating the Community in Waste Management in Reducing Waste of Plastic Mineral Water Glass Packaging and Used Cardboard to achieve good entrepreneurial goals

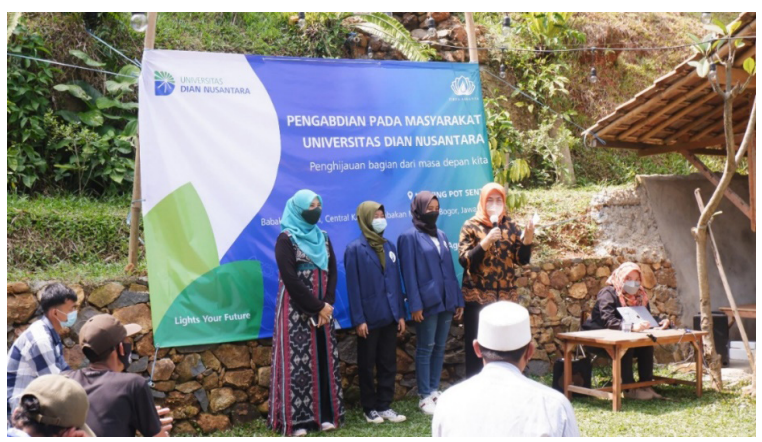

Figure 1. Implementation of Activities

In this community service, our team is more focused on the practice of work through Training Waste Management in Reducing Waste of Plastic Mineral Water Glass Packaging and Used Cardboard in Babakan Ngantai, Karang Tengah Village, Sentul Bogor. This 
service program aims to provide education on Waste Management in Reducing Waste of Plastic Mineral Water Glass Packaging and Used Cardboards in Babakan Ngantai, Karang Tengah Village, Sentul Bogor. Education is delivered in the local language and is followed by free discussion with participants. Response analysis showed that most of the participants were quite good at implementing Waste Management in Reducing Waste of Plastic Mineral Water Glass and Used Cardboard Packaging into creative and economical products. However, most still need time to implement products from Plastic Mineral Water Glass Packaging Waste and Used Cardboard into creative and economical products. The results of the education show that there is a change in the participants' responses.

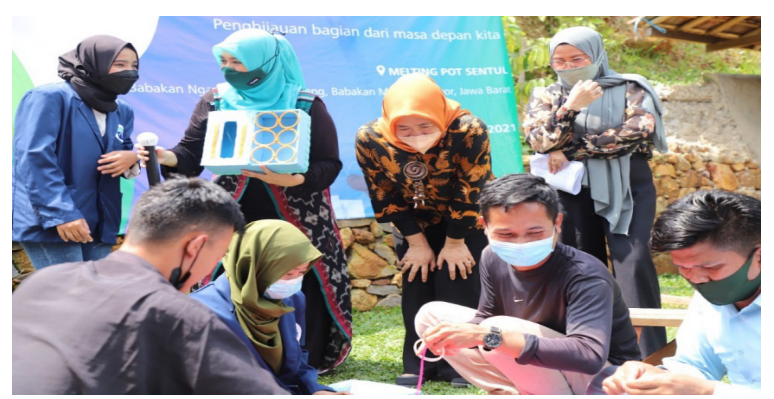

Figure 2. Practice of Waste Plastic Mineral Water Glass Packaging and Used Cardboard

\section{CONCLUSIONS AND SUGGESTIONS}

The conclusions of this activity are:

1. This training activity was able to increase knowledge about Community Empowerment through Waste Management in Reducing Waste of Plastic Mineral Water Glass Packaging and Used Cardboard. It is necessary to carry out continuously activities that are able to build a positive attitude and motivation to: Create a healthier and better life.
2. This activity was responded very positively by the participants, it could be seen from their enthusiasm by asking many questions about great potential, effectively modify participants' attitudes and knowledge regarding Waste Management in Reducing Waste of Plastic Mineral Water Glass Packaging and Used Cardboard into creative and economical products.

This training activity should be carried out continuously for the same participants until they understand and can implement it. Seeing the benefits of this education which is quite large, the target audience should be expanded not only in one village, but there are other villages to follow.

\section{REFERENCES}

Apri Susanto, et al. 2020. Community Empowerment through Waste Management in Reducing Plastic Bottle Waste at Fisherman's Village, Tanjung Ketapang Village. ABDI: Journal of Community Service and Empowerment Vol. 2 No. 2 E-ISSN: 2684-8570| ABDI 2020.

Sri Indriyani S Dai, et al (2019)Community Empowerment Through Waste Management Into Economic Value and the Establishment of a Waste Bank in Pentadu Timur Village, Tilamuta District, Boalemo Regency. Volume 5 No 2, October 2019 http://journal.trunojoyo.ac.id/ pangabdhi ISSN: 2477-6289

Youtube source: Creative Idea Title for Tissue and Mineral Water from Used Goods https://youtu. be/cWgiBHJ9F4A 